\title{
Identidades religiosas no mundo romano:O caso de judeus e cristãos na Ásia Menor dos séculos I e II d.C.
}

\author{
Religious identities in the Roman world: The case of Jews and \\ Christians in the $1^{\text {st }}$ and $2^{\text {nd }}$ centuries $C E$
}

Monica Selvatici ${ }^{\star}$

RESUMO

No quadro dos estudos sobre a questão das identidades religiosas na antiguidade, o presente artigo tem por objetivo analisar a identidade judaica construída pelos judeus da Ásia Menor no século I d.C. e as implicações que tal construção identitária possui sobre a formação e composição étnica das comunidades cristãs nesta mesma região. O artigo se propõe, em seguida, examinar a construção da identidade cristã em meio às relações conflituosas, sobretudo no século II d.C., que a população grega da Ásia Menor e as autoridades romanas mantêm com os cristãos ali residentes. Para tanto, são analisados os textos neotestamentários Atos dos Apóstolos e Apocalipse, além das obras de Justino o mártir e a correspondência entre Plínio o jovem e o imperador Trajano acerca dos cristãos.

Palavras-chave: Identidades. Judeus. Cristãos. Império Romano. Ásia Menor

\section{ABSTRACT}

The purpose of the present paper is to analyze Jewish identity as it is constructed by Asia Minor Jews in the $1^{\text {st }}$ century CE and to observe the implications of such identity construction over the formation and ethnic composition of Christian communities in this area. It is also a purpose to examine Christian identity construction amidst conflicting relations, in the $2^{\text {nd }}$ century CE, among the Greek population of Asia Minor, Roman authorities and Christians living there. In order to do that, the sources into focus are the book of Acts, Revelation, the works of Justin Martyr and the letters concerning Christians exchanged between Pliny the Younger and the emperor Trajan.

Keyword: Identities. Jews. Christians. Roman Empire. Asia Minor.

\footnotetext{
- Doutora em História pela Universidade Estadual de Campinas. Professora Adjunta de História Antiga e Medieval do Departamento de História e do Programa de Pós-graduação em História Social da Universidade Estadual de Londrina.
} 


\section{Introdução}

Larry W. Hurtado (1998), na conhecida obra One God, One Lord, busca analisar a forma pela qual a devoção a Cristo ganhou espaço dentro do monoteísmo judaico (meio no qual ela se originou) uma vez que os judeus do século I d.C. eram muito escrupulosos em relação à crença em seu único Deus, Yahweh. O autor, em sua pesquisa, se opõe ao que eruditos mais antigos haviam afirmado sobre o assunto. Ele recorda Wilhelm Bousset que, no clássico livro Kyrios Christos de $1913^{1}$ afirmava ter sido o judaísmo do período do Segundo Templo fruto de uma forte interação com o ambiente politeísta greco-romano. Para Bousset, a devoção a Cristo como ser divino fora uma novidade dentro do judaísmo semelhante ao culto de outras divindades do mundo politeísta à sua volta. Hurtado, por outro lado, enfatiza corretamente a constatação mais recente de que os judeus no mundo romano eram extremamente apegados aos traços mais importantes do culto judaico, como a crença no Deus único, o pagamento do imposto para o templo de Jerusalém e a observância de importantes regras da Torá, algo que mais os distinguia do que propriamente os assimilava ao universo greco-romano no qual estavam inseridos. E, neste sentido, a devoção a Cristo compreendia uma novidade ainda maior porque não mantinha características próximas à realidade de culto do mundo politeísta, mas correspondia, diferentemente, a um desenvolvimento singular da crença judaica em agentes divinos como o Messias aguardado. Segundo Hurtado (1998, p. $x v)$,

na devoção cúltica a Jesus nos círculos cristãos primitivos, nós temos um desenvolvimento sem paralelos no qual o 'agente principal' é ligado a Deus como um receptor por direito de veneração cúltica, produzindo um novo padrão devocional que é genuinamente 'binitário'.

Para o autor, a devoção a Cristo teve um crescimento rápido e notável em razão das fortes experiências religiosas dos fiéis, sua crença nos milagres operados por Jesus, o que conferiria a ele um status divino, mais especificamente, o título de Filho de Deus.

Hurtado insiste no fato de que os judeus do século I d.C. possuíam fortes escrúpulos em relação a fazer culto a outras figuras que não ao Deus Yahweh. O autor afirma: "mesmo com a inegável diversidade no judaísmo pós-exílico, as evidências indicam que a preocupação com o caráter único de Deus comumente caracterizava as [diversas] seitas judaicas" (HURTADO, 1998, p. 38). Associado a tal escrúpulo acerca do monoteísmo, o judaísmo do período romano "é

\footnotetext{
1 Traduzido para a língua inglesa em 1970 com o título: Kyrios Christos. A History of the Belief in Christ from the Beginnings of Christianity to Irenaeus (Nashville: Abingdon Press, 1970).
} 
caracterizado por uma tendência 'nativista' envolvendo uma ênfase reforçada na fidelidade dos judeus à tradição e à particularidade judaica" (HURTADO, 1998, p. x).

O destaque dado por Hurtado e outros autores, como Paul Trebilco (1991) e John Barclay (1996), ao particularismo judaico na era romana se deve a uma análise mais atenta das fontes judaicas desse período empreendida pelos estudiosos e a um refinamento do grande modelo de análise do desenvolvimento religioso do judaísmo e do cristianismo que vigorou no século XIX e durante a primeira metade do século $\mathrm{XX}$, e que se caracterizava por um entendimento simplista do desenvolvimento histórico de tais crenças a partir da ideia de sincretismo. Segundo tal modelo, o judaísmo do período helenístico e romano, ao interagir/se fundir com o pensamento helênico e com crenças do politeísmo greco-romano, produzira um elemento novo, o cristianismo.

É verdade, no entanto, que existem também diversas evidências nas fontes judaicohelenísticas que apontam para uma forte interação com o pensamento filosófico do mundo helênico, vide os trabalhos de Fílon de Alexandria que buscou utilizar a filosofia grega como instrumento para a interpretação da Bíblia hebraica. ${ }^{2}$ J. J. Collins (1997), conhecido por seu detalhado trabalho de pesquisa sobre o judaísmo helenístico da diáspora, analisa uma seleção de textos produzidos neste meio (como a Carta de Aristeas, os Oráculos Sibilinos e as obras de Fílon de Alexandria). Ao invés de enfatizar os laços de identidade entre os judeus residentes na diáspora como fazem autores como Hurtado, o autor afirma que, em linhas gerais, o que aproxima os textos analisados é a questão da apologia do judaísmo em meio gentílico e a rejeição da idolatria pagã. Para Collins (1997, p. 217), "a maioria dos textos [...] mostra um desejo de partilhar e ser aceita nos estratos mais sofisticados filosoficamente da cultura helenística". O autor privilegia, assim, esse aspecto universalizante do judaísmo em meio helênico em detrimento do particularismo praticado por ele (que Hurtado enfatiza).

Existem, neste sentido, evidências históricas para ambas as posturas - tanto uma ênfase no particularismo quanto um esforço de universalização - praticadas pelos judeus de época helenística e romana em relação à cultura do mundo helênico. Por este motivo, os modelos mais recentes de análise do desenvolvimento judaico e cristão adotam o paradigma da complexidade na análise dos dados e atentam para outros elementos que não apenas o sincretismo entre um judaísmo "puro" e a cultura helênica: verificou-se, por exemplo, que a presença política do Império Romano sobre as áreas onde o judaísmo e o helenismo se encontraram também compreende um fator importante para a forma como tanto a crença judaica quanto o movimento cristão se desenvolveram nos quatro primeiros séculos da era cristã. ${ }^{3}$

Contribuindo para a sofisticação dos modelos de análise acima mencionados, os estudiosos do judaísmo e do cristianismo buscaram no aparato teórico de outras áreas do conhecimento, como a antropologia, certos conceitos segundo os quais analisariam a transformação histórica de ambas as

\footnotetext{
${ }^{2}$ Ver o capítulo sobre Fílon de Alexandria na obra de Barclay (1996, p. 158-180).

${ }^{3}$ Ver, por exemplo, as obras: Goodman (1994) e Horsley (2004).
} 
vertentes religiosas. Um destes conceitos é o de identidade / etnicidade. No presente artigo, adotamos a noção de etnicidade tal como definida pela arqueóloga Siân Jones (1997, p. xiii):

todos os fenômenos sociais e psicológicos associados a uma identidade de grupo culturalmente construída. O conceito de etnicidade se centra sobre os modos pelos quais processos sociais e culturais interagem na identificação de, e na interação entre, grupos étnicos.

A definição de etnicidade segundo Siân Jones incorpora os aspectos mutável e relacional da identidade étnica, e não a apreende mais como algo essencial. A identidade étnica se trata de um elemento relacional porque depende das relações entre o grupo étnico em questão e os grupos ao seu redor; e é mutável porque estas relações são, por sua vez, também mutáveis e dependentes da ação e da interação entre diferentes aspectos sócio-históricos e culturais.

No presente artigo faremos uso dos modelos recentes de análise do judaísmo e do cristianismo ao analisarmos as transformações históricas segundo o viés das identidades mutáveis e relacionais e ao atentarmos, dentro de um cenário histórico complexo, para o papel desempenhado pelo

elemento Roma. Desta forma, é nosso objetivo: a) verificar de que forma as relações entre judeus, a população grega e as autoridades romanas na região da Ásia Menor no século I d.C. têm implicações sobre a composição étnica das comunidades cristãs fundadas nesta área do Império Romano; b) em seguida, analisar a especificidade das relações entre cristãos, a população grega da Ásia Menor e as autoridades romanas, sobretudo, no século II d.C. e a forma como tais relações incidem sobre a vivência da identidade cristã no interior das comunidades de fiéis a Cristo presentes nesta região. Este estudo específico sobre a identidade cristã nas comunidades da Ásia Menor se insere no quadro de pesquisas, por nós desenvolvido, sobre a presença da prática judaizante nas comunidades cristãs relacionando-a ao contexto maior da vida de cristãos e judeus no Império Romano.

\section{As cidades da Ásia Menor e o culto aos governantes}

A escolha pela análise da região da Ásia Menor no período romano não é aleatória. Muitos são os indícios históricos de conflitos entre a população das cidades gregas desta área e judeus e, mais tarde, cristãos no que diz respeito ao culto às divindades e, em especial, ao culto ao imperador romano. O contexto de animosidades é resultado do desenvolvimento específico nesta região de 
uma tradição ligada ao culto do governante, além do já praticado culto às divindades protetoras (ou padroeiras) das diversas cidades gregas ali presentes.

A realização de cultos ao governante remonta ao início do período helenístico, com o domínio de Alexandre o grande sobre toda a região da Ásia Menor (PRICE, 1984, p. 23-52). Anterior a isto, não havia sido prática nas cidades gregas a elevação de um líder à condição de divindade e, por conseguinte, a realização de um culto à pessoa dele. Esta situação se modificou com a chegada de Alexandre como rei / imperador (basileus) e seus sucessores. Afinal, o poder passava agora a emanar de outro lugar e não da própria cidade, já que Alexandre submetera a seu domínio um vasto território. Simon Price (1984, p. 28) afirma: "o ponto fundamental é que a relação da cidade grega com os novos governantes foi e permaneceu problemática”. A hipótese defendida por Price é a de que as cidades gregas estabeleceram cultos aos governantes helenísticos como uma tentativa de aquiescer a um novo tipo de poder, o dos reis gregos. Este poder se tratava de uma novidade porque, até então, os governantes exteriores às cidades haviam sido estrangeiros: os persas. Para os novos reis gregos, Price (1984, p. 30) acredita que, na ausência de respostas legais para tal nova realidade de poder, "os cultos dos deuses foram o modelo disponível a eles para a representação de um poder do qual a cidade era dependente que era externo, e ainda assim grego".

O autor levanta dois importantes exemplos dos cultos estabelecidos. Ambos dizem respeito à extensão do poder do sucessor de Alexandre, Antíoco III da dinastia selêucida, ${ }^{4}$ sobre as cidades ocidentais da Ásia Menor. O primeiro exemplo é a libertação da cidade de lasos por Antíoco III do controle de Felipe $V$ da Macedônia em 197 a.C. e a resposta em forma de um altar erigido e honras adicionais conferidas pelos cidadãos ao rei como o resultado de sua proteção e atitude benevolente. A rainha Laodiceia, esposa de Antíoco, também foi agraciada com um culto (em associação à deusa Afrodite) quando concedeu dotes às filhas dos cidadãos pobres de lasos. Por fim, o culto a ambos o rei Antíoco III e sua esposa se tornou central na vida política e social da cidade. O segundo exemplo é o da cidade de Teos que, submetida ao poder da dinastia dos atálidas de Pérgamo, apelou junto a Antíoco III para que a protegesse. Este lhe concedeu o caráter sagrado e inviolável e a isenção do pagamento de tributos. Em retribuição, a cidade - dividida em diversos agrupamentos cívicos com seus respectivos altares - estabeleceu o culto a Antíoco e Laodiceia realizando sacrifícios oficiais sob as instruções do sacerdote do rei (PRICE, 1984, p.30).

O argumento desenvolvido por Simon Price é muito interessante. No entanto, atribui o culto aos governantes helenísticos a uma exclusiva iniciativa das cidades da Ásia Menor em sua busca por conferir inteligibilidade e reconhecimento à presença de tais soberanos. Price não parece levar em conta a política adotada pelos próprios soberanos helenísticos de associação de sua imagem àquela de uma divindade como forma de conferir legitimidade a seu poder. No caso dos selêucidas acima mencionados, tal associação ficava registrada na cunhagem de moedas. Antíoco I criou o

\footnotetext{
4 Antíoco III recebeu o epíteto 'o grande' porque representou o ápice do poder selêucida. No entanto, como o reino selêucida mantinha um território muito vasto sob seu poder (desde a parte ocidental da Ásia Menor até o reino da Báctria a leste), logo começou a perder seus territórios nos extremos ocidental e oriental. Roma se tornara o grande inimigo a ser combatido. (SELVATICI, 2012).
} 
modelo monetário no qual o retrato do rei ocupava o anverso e a imagem do deus Apolo sobre o ônfalo o reverso das moedas. Também promoveu a imagem de seu pai Seleuco I como o fundador da dinastia, afastando-a da figura primeira de Alexandre o grande. Ao divulgar a imagem de seu pai, morto e divinizado, em moedas que seguiam o modelo ligado ao deus Apolo, Antíoco I se colocava como sucessor legítimo dele. Mais tarde, inseriria sua própria imagem no anverso das moedas. De acordo com Kyle Erickson (2010), Antíoco

divulgou a imagem de Seleuco como ancestral e fundador da dinastia, mas não como o único foco da casa real. O papel de Seleuco como fundador foi ainda mais destacado através do contínuo uso da data de seu retorno da Babilônia como o marco inicial da cronologia da dinastia selêucida.

Em suma, a nosso ver existe uma relação direta entre a iniciativa da prestação de cultos aos governantes helenísticos por parte das cidades gregas e um fomento dela por parte de tais soberanos por meio de toda a política de legitimação de seu poder empreendida através de sua associação com a imagem de divindades gregas.

Sob o domínio romano, a prática de culto aos governantes como forma de retribuição (e novos pedidos) às benesses por eles concedidas já se tornara tradicional nas cidades da Ásia Menor. Assim, no início do regime do Principado em 27 a.C., quando o senado romano conferiu a Otávio o título de Augusto - o "agraciado pelos deuses" -, rapidamente se desenvolveu o culto à figura imperial do princeps, desta vez não como iniciativa dele, mas como iniciativa das próprias cidades da Ásia Menor, agora agrupadas em regiões maiores (antigos reinos dissidentes do grande reino selêucida) e transformadas em províncias romanas.

\section{Acerca dos judeus na Ásia Menor do século I d.C.}

As relações políticas entre os romanos e os judeus remontam a meados do século II a.C., momento em que Roma apoiou os judeus palestinos quando estes se libertaram do domínio selêucida após a revolta dos Macabeus. Quando os territórios do antigo reino selêucida foram finalmente incorporados aos domínios romanos, e em retribuição ao apoio judaico dado ao partido de César, contra aquele de Pompeu, a decisão de César foi a adoção, na segunda metade do século I a.C., de medidas de proteção aos judeus e a seu culto. ${ }^{5}$ Tais medidas se traduziram na

\footnotetext{
${ }^{5}$ Clifford Ando destaca, neste sentido, o conceito de 'agenciamento' em relação aos provinciais. Ele insiste na questão de que os súditos do império agiam em nome de seus interesses e barganhavam alianças com Roma desta forma. Não recebiam de forma passiva as medidas políticas impostas pelas autoridades
} 
permissão da reprodução das práticas religiosas judaicas mais importantes e na declaração da santidade de suas escrituras (SMALLWOOD, 1999, p. 168-191). Há que se mencionar também a isenção, embora temporária e aplicada de forma local, dos judeus em relação à obrigatoriedade do recrutamento militar (PUCCI BEN ZEEV, 1998, p. 440-1) e sua isenção total e completa em relação ao culto aos deuses das cidades onde residiam.

Tais práticas religiosas judaicas demonstravam, na realidade, a questão do separatismo judaico suscitada pela crença dos judeus na eleição, única e exclusivamente, de seu povo por Yahweh. E este separativo fomentava certa desconfiança e manifestações hostis por parte da população gentílica circundante. Neste sentido, a concessão de privilégios e de proteção especial aos judeus por parte de Roma, ao invés de reprimir o sentimento antijudaico generalizado, causou, na realidade, o seu recrudescimento.

A Ásia Menor, como vimos, era um território dominado pelos cultos aos deuses protetores das diferentes cidades. Os judeus, como observado acima, estavam isentos de tais cultos, algo que irritava bastante os gentios. Paul Trebilco (1991, p. 34), em seu estudo sobre as comunidades judaicas da Ásia Menor, assevera que os privilégios que os judeus reivindicaram e receberam de Roma permitiram a eles "manter a sua identidade judaica [na expressão do autor em inglês, "Jewishness"] em face à hostilidade local". Trebilco observa, num panorama geral da identidade judaica manifestada pelos judeus da Ásia Menor, uma série de características que reforçam essa identidade em termos de suas particularidades propriamente judaicas. Assim, o autor lista: tais judeus estavam comprometidos "com a sinagoga, com o imposto do templo, com o templo e o seu culto, com o culto ao sábado, com as leis de comida, enfim, com a vivência de acordo com as suas próprias tradições" (TREBILCO, 1991, p. 34).

Dentre as fontes para um estudo da identidade judaica na Ásia Menor no século I d.C., os textos do Novo Testamento são importantes por fornecer evidências sobre a situação dos judeus em diferentes províncias dessa região mais ampla.

O autor de Atos dos Apóstolos atribui a origem do apóstolo Paulo à cidade de Tarso, capital da província romana da Cilícia. Dados na epístola paulina aos gálatas parecem indicar que esta informação de Lucas esteja correta. Não há trabalhos específicos sobre os judeus da província da Cilícia. Ainda assim, essa província estava localizada no quadro maior da Ásia Menor, a nordeste do mar Mediterrâneo. Como afirmado acima, ela tinha por capital a cidade de Tarso. O geógrafo antigo Estrabão caracteriza Tarso de forma elogiosa e um tanto quanto exagerada:

romanas. Este foi o caso dos judeus ao reivindicarem seus direitos junto a Júlio César no final do período republicano. De acordo com Ando (2010, p. 45), "Muito agenciamento foi exercido pelos provinciais, cujas instituições privadas vieram a ecoar os padrões de diferenciação social estrutural que receberam articulação normativa [...] em documentos públicos do império e suas comunidades constituintes". 
os habitantes de Tarso dedicam-se tão avidamente não só à filosofia, mas também a todo o conjunto da educação em geral, que já ultrapassaram Atenas, Alexandria, e qualquer outro lugar que possa ser citado onde haja escolas e palestras de filósofos... [Ela] tem todos os tipos de escolas das artes retóricas; e em geral não tem apenas uma população numerosa, mas também muito poderosa, assim mantendo a reputação da cidade natal. (MURPHY-O'CONNOR, 2000, p. 50).

No entanto, mesmo sendo oriundo desta metrópole cultural, Paulo não parece ter buscado uma integração maior com o ambiente filosófico mais amplo da cidade. A linguagem utilizada por ele não aponta para uma formação em artes retóricas de sua parte. ${ }^{6}$ Martin Hengel (1991) destaca neste sentido, a ignorância de Paulo acerca da literatura grega clássica e a ausência de referências à poesia grega em suas epístolas. O único verso que o missionário cita, em 1 Cor. 15:33, da obra Thais do poeta cômico Menandro ("as más companhias corrompem os bons costumes"), já havia se tornado um ditado popular destacado de seu contexto literário. ${ }^{7}$

De igual maneira, por muito tempo se acreditou que Paulo fosse um iniciado nas filosofias pagãs e nas religiões de mistério helenísticas. Afinal, a cidade de Tarso era conhecida pela forte presença da filosofia estoica no século I. Entretanto, não são muitos os elementos de um pensamento estoico que se mostram visíveis em suas epístolas, apenas o trecho de Romanos 2:1216 e, em linhas mais gerais, o conteúdo da epístola aos Filipenses.

Paulo era um judeu originário da Cilícia que, ao contrário de desenvolver uma identidade judaica em termos dos aspectos comuns entre o seu judaísmo e a atmosfera do pensamento filosófico helenístico que o cercava, optou por construir sua identidade judaica baseada na ênfase às características particulares dos judeus: ele abandonou sua cidade natal e foi estudar em Jerusalém e se tornar fariseu. ${ }^{8}$ Os estudos de etnicidade recentes têm percebido que um meio favorável contribui para a maior integração dos membros de um grupo étnico a esse meio e, em contrapartida, um meio desfavorável, hostil, provoca nos membros do grupo étnico em questão a reação da autopreservação por meio do reforço da identidade étnica, ${ }^{9}$ o que Paulo demonstra ter feito. A trajetória inicial da figura de Paulo, dentro do judaísmo, é aqui tomada de maneira a levantar

\footnotetext{
${ }^{6}$ Em 2Cor 10:10, Paulo reclama que os coríntios descrevem seu modo de falar / sua palavra como desprezível (no grego, "ho lógos exouthenēménos").

${ }_{7}^{7}$ Hengel (1991, p. 3), Werner Jaeger (1991, p. 25, nota 28) recorda que Clemente de Alexandria foi o primeiro autor a prestar atenção às citações literárias da poesia grega presentes no NT. Segundo ele, além da referida citação em 1Cor. 15:33, pode-se identificar outra na epístola a Tito 1:12, e aquela em At. 17:28, no discurso que Lucas põe na boca de Paulo no Areópago em Atenas.

${ }^{8}$ No pequeno discurso autobiográfico de Filipenses 3:5-7, Paulo afirma: "circuncidado ao oitavo dia, da descendência de Israel, da tribo de Benjamin, hebreu filho de hebreus; quanto à Lei, fariseu; quanto ao zelo, perseguidor da Igreja; quanto à justiça que há na Lei, irrepreensível".

${ }^{9}$ No trabalho Selvatici (2008), analisamos as diferentes atitudes adotadas pelos judeus em duas cidades helenizadas no século I d.C. que mantinham contextos sociais diametralmente opostos: Alexandria, na qual ocorria violência contra a comunidade judaica; e Antioquia da Síria, cidade muito cosmopolita e importante passagem de rotas comerciais, onde a comunidade judaica era respeitada pela população local.
} 
a hipótese de que os judeus da província romana da Cilícia, no quadro maior da Ásia Menor, vivessem num contexto social desfavorável, caracterizado pela hostilidade por parte dos gentios que os cercavam.

Diante do panorama analisado por Trebilco, a trajetória inicial de Paulo dentro do judaísmo com o seu abandono da terra natal e a escolha por seguir o estudo do farisaísmo em Jerusalém parece corroborar o contexto de um compromisso muito forte dos judeus da Ásia Menor em relação às crenças, instituições e práticas de seu povo e, sobretudo, em relação à terra santa. Em vista de a trajetória inicial no judaísmo do famoso missionário cristão se encaixar perfeitamente nesse contexto, poderíamos levar adiante a hipótese e perguntar: será que, entre as razões que teriam levado Paulo a escolher a cidade de Jerusalém como novo lar, a tradição farisaica como modo de vida e um zelo enorme pela Lei que o fez mesmo perseguir cristãos que abdicavam dessa Lei em nome de seu novo culto a Cristo, estaria a hostilidade sempre presente dos gentios na cidade de Tarso? Essa hipótese é bastante plausível diante das evidências analisadas.

Atos dos Apóstolos também faz referência às comunidades judaicas de outra província na Ásia Menor, a Ásia, em passagens sobre os judeus helenistas zelosos pela Lei em Jerusalém. Das quatro passagens ao total, em três delas aparecem 'judeus da Ásia': em 6:9 “Intervieram então alguns da sinagoga chamada dos Libertos, dos cireneus e alexandrinos, dos da Cilícia e da Ásia, e puseram-se a discutir com Estevão"; em 21:27-8, quando Paulo entra no templo para se purificar, "os judeus da Ásia amotinaram toda a multidão e o agarraram, gritando: 'Homens de Israel, socorro! Este é o indivíduo que ensina a todos e por toda parte contra o nosso povo, a Lei, e este lugar! Além disso, trouxe gregos para dentro do templo, assim profanando este santo lugar'”; e, por último, em 24:17-9, quando Paulo, em seu discurso diante do governador romano, desafia "alguns judeus da Ásia" a se apresentarem diante do governador e a acusarem-no, caso realmente tenham provas de apostasia contra ele. ${ }^{10}$

Além disso, no relato da segunda viagem missionária de Paulo às sinagogas da diáspora mediterrânea, Lucas usa um recurso interessante para explicar porque Paulo e Silas não evangelizam as cidades da Ásia: eles "foram impedidos pelo Espírito Santo de anunciar a palavra" na região.

Esta menção frequente às dificuldades de Paulo com os judeus da Ásia parece sugerir um comportamento de repúdio constante de tais judeus não só à pregação cristã de Jesus como o Messias, mas também às implicações desse fato. Por quê?

A província da Ásia possuía no século I numerosos altares a deuses benfeitores. Para tornar o quadro geral ainda mais complexo e problemático, a partir do momento em que o senado romano conferiu a Otávio o título de Augusto, em 27 a.C., desenvolveu-se rapidamente o culto imperial à figura de Augusto. A Ásia e a Bitínia foram as primeiras províncias a pedirem permissão a ele para a realização do culto à sua pessoa (PRICE, 1984, p. 58).

${ }^{10}$ Grifos adicionados. 
Desta forma, no fim do principado de Augusto, uma série de delegações judaicas da Ásia vai apelar junto ao imperador contra as muitas infrações das autoridades citadinas aos seus direitos e também contra as várias manifestações de violência da população gentílica em relação às suas comunidades naquela província. Mais tarde, quando ocorrem os eventos relacionados a Paulo e aos judeus da Ásia em Jerusalém, a memória que tais judeus possuem de sua história naquela província é de conflito e hostilidade generalizados por parte da população gentílica.

Simon Price (1984) tem outra opinião sobre a questão de como os judeus foram afetados pela instituição do culto ao imperador. Ele acredita, diferentemente dos cristãos algumas décadas mais tarde, que os judeus soubessem acomodar a prática do culto ao imperador a uma simples homenagem (ou pedidos em favor da saúde do imperador, feitos por meio de sacrifícios a Yahweh no templo de Jerusalém). É certo, com efeito, que as autoridades romanas não perseguiram os judeus em razão de sua não realização do culto ao imperador. Tal atitude benevolente do poder romano parece, assim, ter contribuído para a manutenção da hostilidade gentílica contra os judeus na Ásia Menor desse período.

Além das fontes escritas levantadas, certos dados arqueológicos ligados a túmulos judaicos da região da Ásia Menor também apontam no sentido de uma procura de tais judeus pela preservação dos traços propriamente ligados aos rituais e práticas judaicos em detrimento de uma integração cultural maior com o mundo helênico circundante: em toda a Ásia Menor, não foram encontrados epitáfios com inscrições métricas redigidas em grego (um costume amplamente disseminado) nos túmulos judaicos antigos ali achados. ${ }^{11}$ Se pensarmos em termos da questão da etnicidade, observamos que esta região é caracterizada por conflitos sociais entre judeus e não judeus frequentes por volta do século I d.C. Há, por este motivo, indícios fortes de um repúdio de tais judeus aos costumes e práticas reproduzidas no meio hostil dominante e do seu fechamento no interior da comunidade judaica que integravam, de maneira a reforçar sua identidade através da reprodução dos costumes e práticas judaicos.

Após todo esse esforço de reconstrução histórica das relações entre judeus, a população grega e as autoridades romanas na região da Ásia Menor no século I d.C., retornamos ao primeiro objetivo de nosso estudo, qual seja: compreender as implicações de tais relações sociais problemáticas sobre a composição étnica das comunidades cristãs fundadas nesta área do Império Romano.

O livro de Atos narra que, ao longo da trajetória de Paulo de Tarso de pregação do Cristo ressuscitado aos judeus residentes na região do Mediterrâneo oriental, a resposta de tais judeus foi o repúdio generalizado à mensagem trazida pelo missionário. Tal pregação da Boa Nova cristã seguida do repúdio pelos judeus da diáspora grega aparece em diversas passagens do livro neotestamentário, o que fez com que alguns autores duvidassem da autenticidade da informação, entendendo-a apenas como um recurso retórico (SANDERS, 1983, p. 179-180; MURPHYO'CONNOR, 2000, p. 22) de Lucas para demonstrar que Paulo não abandonou repentinamente seu

11 Já em Alexandria e em Roma, apenas um único epitáfio de um túmulo judaico com esse tipo de inscrição em grego foi encontrado em cada uma das duas cidades. Ver, em detalhes, J. W. Van Henten e Pieter Van Der Horst (1994). 
povo em favor dos gentios logo após a conversão. No entanto, Paulo em 2Cor 11:24, fornece uma informação importante e negligenciada por esses autores. Aquela de que por cinco vezes ele recebeu dos judeus "os quarenta golpes menos um", uma prática punitiva difundida no meio judaico.

Dentre as ofensas punidas com os trinta e nove golpes, estavam a não observância dos mandamentos da comunidade e o falso testemunho. É muito provável que Paulo tenha recebido esse castigo nas comunidades judaicas da Ásia Menor, sendo acusado de falso testemunho por sua pregação da mensagem do Cristo ressuscitado. Mas por que teriam esses judeus respondido de maneira tão hostil à mensagem cristã de Paulo?

Uma boa explicação para essa reação extremamente negativa dos judeus do Mediterrâneo grego à Boa Nova cristã é oferecida por Paula Fredriksen (1991). A autora levanta fatores sóciopolíticos para a hostilidade das comunidades judaicas da diáspora em relação à mensagem trazida por Paulo (e seu companheiro de viagem Barnabé): o medo que tais judeus tiveram do impacto sobre os habitantes locais gentios da proclamação de um Messias executado muito recentemente por Roma e de um fim iminente, a ser concretizado com a chegada de um reino messiânico por ele governado. Fredriksen (1991, p. 556) afirma o seguinte: "A disseminação aberta de uma mensagem messiânica punha toda a comunidade judaica em risco", na medida em que poderia indispor as autoridades romanas, que até então asseguravam proteção às frágeis e já hostilizadas comunidades judaicas. Sem a proteção do poder romano e, possivelmente tendo também ele como inimigo, o destino de tais comunidades judaicas seria a extinção completa (SELVATICI, 2002, p. 109-113).

As relações problemáticas entre judeus e a população grega da Ásia Menor, associadas ao receio de uma retaliação por parte das autoridades romanas à divulgação da mensagem da chegada de um Messias, um salvador e novo senhor, Jesus Cristo, tanto para judeus como para gentios, fez com que os judeus das comunidades da diáspora grega hostilizassem Paulo e rejeitassem sua proclamação. Este seguiu pregando apenas àqueles que aceitaram sua mensagem, os tementes a Deus - não judeus simpatizantes da fé judaica que frequentavam as sinagogas às quais Paulo fora levar a Boa Nova do Cristo ressuscitado. Por este motivo, a composição étnica das comunidades de crentes em Jesus formadas por Paulo no Mediterrâneo grego e, em especial, na Ásia Menor era, sobretudo, de não judeus de cultura grega.

\section{Sobre os cristãos na Ásia Menor (90 d.C. - século II d.C.)}

Sabemos, a partir da reconstrução histórica acima realizada que as comunidades de cristãos na Ásia Menor eram compostas, em sua maioria absoluta, por não judeus. Analisaremos agora a 
especificidade das relações entre cristãos, a população grega desta região e as autoridades romanas, entre fins do século I d.C. e o século II d.C., e a forma como tais relações incidem sobre a vivência da identidade cristã no interior das comunidades de fiéis a Cristo desta região. Discutiremos, especificamente, os possíveis motivos para a presença de cristãos judaizantes em tais comunidades. A judaização consistia na reprodução de práticas e rituais judaicos, não adotados, a princípio, pelas comunidades cristãs paulinas quando de sua constituição e nem incentivados pela recomendação do apóstolo Paulo.

Evidências da prática da judaização já em meados do século I d.C. aparecem na epístola aos gálatas (na qual ela é muito criticada por Paulo) e na segunda metade deste século no relato de Atos dos Apóstolos, com sua menção declarada aos 'cristãos fariseus' e outra implícita ao longo de todo o relato. No entanto, não é nosso objetivo discorrer sobre elas porque no período em questão uma distinção entre judeus e cristãos ainda não era feita pelas autoridades romanas. ${ }^{12}$ Assim, ambos os grupos apareciam ao poder romano como vertentes no interior do quadro mais amplo do judaísmo. Analisaremos, diferentemente, os textos em que aparece a questão da judaização nas comunidades cristãs da Ásia Menor no período em que a distinção entre judeus e cristãos já era possível aos olhos de Roma.

No livro do Apocalipse há menções significativas aos prováveis judaizantes quando o autor se refere à 'sinagoga de Satanás'. A historiografia recente entende que a obra tenha sido produzida na década de 90 d.C. nos últimos anos do governo do imperador Domiciano. Em duas passagens do livro, o autor João de Patmos, ao se dirigir a comunidades cristãs da Ásia Menor, afirma o seguinte:

Conheço as tuas obras, e tribulação, e pobreza (mas tu és rico), e a blasfêmia dos que se dizem judeus, e não o são, mas são a sinagoga de Satanás (ek tōn legóntōn loudaíous einai heautoùs kaì ouk eisìn allà sunagōgē tou satanã). (Ap. 2,9)

Eis que eu farei aos da sinagoga de Satanás, aos que se dizem judeus, e não são, mas mentem (ek tēs sunagōgēs tou satanã tōn legóntōn heautoùs loudaíous einai, kaì ouk eisìn allà pseúdontai): eis que eu farei que venham, e adorem prostrados a teus pés, e saibam que eu te amo. (Ap. 3,9). (grifos adicionados)

David Frankfurter (2001, p. 421-22) argumenta a respeito desta questão:

A preocupação de João com o falso caráter judaico de seus oponentes parece girar em torno da questão da incorporação ritual de gentios em um

${ }^{12}$ Uma análise sobre os judaizantes presentes nestas obras se encontra em Selvatici (2013). 
movimento de Jesus essencialmente judaico e pode muito bem estar ouvindo os debates sobre a circuncisão do tempo de Paulo. [...] Assim, os "que se dizem judeus" teriam sido gentios que estavam observando algum grau da prática judaica de acordo com a instrução de Paulo; por isso "agindo como judeus". [...] Esses oponentes eram parte da ala paulina ou neopaulina do movimento de Jesus. [...] [Eles] são reprováveis porque são gentios que estão observando insuficientemente a prática judaica. As objeções de João giram em torno de questões como pureza na preparação para a parousia, pureza para a intimidade com o mundo celestial e pureza necessária para se receber visões de Cristo. A impureza dos "que se dizem judeus" ameaçava a coesão dos Eleitos no fim dos tempos. (grifos adicionados)

Para Frankfurter, a acusação de João de Patmos se dirige a gentios cristãos que não estão observando de forma completa todas as regras de pureza da Torá, necessárias, segundo seu ponto de vista, para a vivência na comunidade dos eleitos ao Reino de Deus.

A autora Michele Murray, por sua vez, também entende serem aqueles da 'sinagoga de Satanás' gentios cristãos que estavam adotando práticas judaicas, mas não aprofunda a discussão acerca do grau de obediência maior ou menor a tais rituais, como procura fazer Frankfurter (2004, p. 78). Ela afirma o seguinte:

Os oponentes referidos em 2:9 e 3:9 - identificados como parte da 'sinagoga de satã' em Esmirna e Filadélfia - estão reivindicando a identidade étnica judaica, mas não a têm. A mais lógica e óbvia interpretação das acusações de João é a de que ele estava se referindo a gentios que falsamente afirmavam ser judeus e adotavam o estilo de vida judaico.

Esses gentios poderiam ter sido gentios não cristãos, mas o tom hostil das acusações torna mais plausível que os judaizantes fossem cristãos [...]. A forte condenação de João a 'aqueles que dizem que são judeus e não são' revela o sentido profundo de traição e animosidade que ele sente em relação àqueles cristãos que se desviaram do comportamento que considerava aceitável.

O aspecto interessante levantado por Murray é a busca por encontrar uma explicação para a judaização dos cristãos gentios no contexto mais amplo de sua vida sócio-política dentro do Império Romano. Assim, Murray (2000, p. 154) acredita que 
o autor do Apocalipse expressa hostilidade em relação a um grupo de cristãos gentios que adotaram costumes judaicos e chamaram a si mesmos de judeus, provavelmente de forma a evitar a perseguição [romana].

Esta perseguição romana, atenta a autora, não era direcionada aos judeus do império porque eles dispunham de isenções e privilégios conferidos a seu culto e modo de vida pelos romanos desde os tempos de Júlio César - algo que não ocorria com os cristãos cuja presença como grupo separado do judaísmo era percebida pelas autoridades romanas desde o governo de Nero e da perseguição por ele promovida. Os cristãos, em seu próprio culto, não mantinham rituais sacrificiais, e se recusavam a fazer qualquer tipo de homenagem ao imperador e, por isso, se tornavam alvo das denúncias dos provinciais e, consequentemente, da punição das autoridades romanas.

A análise de Murray é interessante por apontar a vida sócio-política dos cristãos no Império Romano como aspecto importante para a compreensão da prática judaizante pelos cristãos de origem gentílica. Ainda assim, o consenso da historiografia recente ${ }^{13}$ quanto ao caráter polêmico do livro do Apocalipse é o de que o seu autor busca insuflar os leitores cristãos - já muito condescendentes em relação à vida mundana no Império - contra a ordem imperial romana, e não que o livro seja uma resposta a um contexto de perseguições declaradas contra os cristãos. Com efeito, não existem maiores indícios de que o imperador Domiciano tenha promovido perseguições aos cristãos em seu governo.

Evidências notórias da identificação dos cristãos pelos romanos só aparecem em fontes do início do século II d.C.: na carta do governador Plínio, o jovem, da província da Bitínia ao imperador Trajano, ele pede orientações sobre como lidar com a questão dos cristãos em sua província. $O$ governador se dirige a Trajano da seguinte maneira:

Até o momento não atuei contra os cristãos e não sei, assim, quais fatos e em que medida devem ser punidos ou processados. Pergunto-me [...] se deve perdoar-se o arrependido ou se o verdadeiro cristão em nada muda o desdizer-se, se deve punir-se o cristão enquanto tal, mesmo sem delito, ou se apenas segundo os delitos dessa denominação. Nesse ínterim, segui os seguintes procedimentos com relação aos que se me apresentaram como cristãos. Perguntei-lhes, pessoalmente, se eram cristãos. Aos que confessaram, perguntei-lhes duas, três vezes. Os que não voltaram atrás foram executados. Qualquer que fosse o sentido de sua fé, sabia que sua pertinácia e obstinação tinham de ser punidas. [...] Afixou-se, então, um cartaz, sem assinatura com um grande número de nomes. (Cartas 10,96)

${ }^{13}$ Ver Yarbro (1984), Raymond Brown (1997, p. 805-809) não acredita em uma perseguição generalizada aos cristãos sob Domiciano, apenas em atitudes de suspeita em relação ao culto cristão adotadas pelo imperador. 
Trajano, em seu rescrito a Plínio, afirma que ele agira de forma correta, punindo apenas os cristãos que tivessem se mantido convictos. No entanto, recomenda que Plínio não leve em consideração acusações anônimas porque "as denúncias anônimas não podem ter qualquer valor, em nenhum caso, pois esse péssimo tipo de comportamento não é mais de nosso tempo" (Cartas $10,97)$.

Trajano se mostra um governante cauteloso ao aconselhar Plínio a não dar atenção a denúncias anônimas. Entretanto, Plínio em seu texto nos deixa entrever que a população da Bitínia era muito hostil à presença de cristãos em seu meio e mantinha a prática das denúncias anônimas, como o cartaz com o "grande número de nomes". Lembremos que a Bitínia, juntamente com a Ásia, foram as duas províncias da Ásia Menor a tomarem a iniciativa da realização de culto ao imperador Augusto. A proximidade de cristãos que não faziam este culto, nem os cultos tradicionais às divindades protetoras de suas cidades, em muito incomodava os provinciais da Bitínia.

Outra importante fonte acerca da judaização de cristãos de meados do século II d.C. é Justino o mártir, que foi um gentio originário da Palestina que viveu em Éfeso e foi martirizado como cristão em Roma em torno de 165. Conhecedor das filosofias gregas, ele finalmente se tornou um cristão. O texto Diálogo com Trífon reflete algumas objeções aparentemente feitas por judeus ao movimento cristão e se caracteriza por uma refutação de Justino a tais objeções de teor judaico ou judaizante. No entanto, tal refutação é compreendida na atualidade como tendo os cristãos da comunidade cristã do autor como público alvo e não judeus exteriores à igreja cristã (SENA PERA, 2009, p. 4655). Justino escreve o Diálogo respondendo a cristãos judaizantes.

Em outra obra sua, a Primeira Apologia, Justino dá testemunho das perseguições aos cristãos ocorridas em seu tempo na província da Ásia, onde residiu na cidade de Éfeso. Paul Keresztes (1967, p. 124) afirma que: "o fato fundamental da narrativa de Justino é que os cristãos eram [...] sentenciados à morte, em razão de sua profissão da fé cristã" ou simplesmente do nome cristão. Sobre isso, o próprio Justino exorta:

não se deve julgar que alguém seja bom ou mau por levar um nome, se prescindimos das ações que tal nome supõe. Além disso, se se examina aquilo de que nos acusam, somos os melhores homens. Todavia, como não consideramos justo pretender que nos absolvam por nosso nome se estamos convictos de maldade; do mesmo modo, se nem por nosso nome, nem por nossa conduta se constata que tenhamos cometido crime, o vosso dever é empenhar-vos para não vos tornardes responsáveis de castigo, condenando injustamente aqueles que não foram convencidos judicialmente (I Apologia $4,1-2)$. 
Segundo a análise de Keresztes (1967, p. 127),

Não é difícil perceber como o padrão helenístico de hostilidade das massas contra os judeus "ateus" poderia ser transferido para uma seita que era entendida como um fruto do judaísmo, e que na opinião popular no oriente era ainda mais perigosa e desagradável que sua predecessora. A história fornece evidências de que os cristãos eram tratados de modo bem similar aos judeus tanto no oriente grego como em Roma. Com exceção do episódio neroniano e de alguns outros casos espalhados aqui e ali, eles, tal como os judeus, foram deixados em paz e viveram uma vida relativamente pacífica em Roma durante os dois primeiros séculos. Por outro lado, como nós vimos durante o mesmo período, foi praticamente apenas o mundo helenístico que sujeitou cristãos - e judeus - à violência, abusos e julgamentos sob a forma de pogroms. A história do cristianismo nesta época [...], e o testemunho da Primeira Apologia de Justino, dão ampla evidência de que os cristãos eram submetidos a julgamentos públicos sob a acusação de "ateísmo". Esses julgamentos eram uma instituição helenística ligada a apresentações públicas.

Em nosso entender, Keresztes está correto ao frisar a violência adotada pelo mundo oriental helenístico - leia-se, em especial, a Ásia Menor - contra judeus e cristãos. No entanto, ao entendêlos como semelhantes e, neste sentido, como alvos óbvios da hostilidade da população não judaica e não cristã desta região, o autor não leva em consideração - e não provê nenhuma explicação para - o fato de que muitos cristãos de origem gentílica buscaram, nas comunidades cristãs da Ásia Menor, adotar práticas e rituais judaicos.

Keresztes em sua explicação negligencia o aspecto crucial de que o mundo oriental helenístico era um mundo politicamente dominado por Roma. Observado este aspecto, os indícios começam a apontar para a importância das relações que tanto judeus quanto cristãos mantiveram com as autoridades romanas. Enquanto os primeiros tiveram desde muito cedo seus direitos e costumes ancestrais assegurados pelo poder romano (frente às muitas demonstrações de hostilidade da população grega circundante), os últimos, uma vez enxergados como um grupo à parte por este mesmo poder, ficaram à margem de qualquer proteção imperial e à mercê das acusações de ateísmo uma vez que não faziam o culto imperial ou aquele às divindades das cidades. $\mathrm{E}$ esta acusação os levava a julgamentos públicos, tal como observado no rescrito do imperador Trajano.

No século II d.C. o simples nome 'cristãos' passava a se transformar em motivo para que membros deste grupo fossem levados a julgamento, algo que Justino o mártir tanto deseja modificar quando argumenta em sua Primeira Apologia que o nome 'cristão' não é prova de crime algum mas, ao contrário, que os cristãos, por manterem bons valores, são excelentes súditos do Império. 
Analisado o contexto de perseguições imperiais aos cristãos ao longo do século II d.C., parece muito correto afirmar que uma importante motivação para os cristãos de origem gentílica das comunidades da Ásia Menor terem praticado a judaização foi a busca por fugir a tais perseguições, ${ }^{14}$ ao se assemelharem em termos de rituais e práticas aos judeus, judeus esses que continuavam a dispor de isenções especiais conferidas pelo poder romano, como aquela do culto imperial e dos cultos às divindades protetoras. Neste sentido, observamos que as implicações das relações conflituosas entre cristãos, gregos e autoridades romanas na Ásia Menor sobre a vivência da identidade cristã nas comunidades cristãs ali presentes seguem no sentido de aproximar tais cristãos da realidade de culto judaica com a adoção de práticas e rituais distintamente judaicos.

\section{Conclusão}

Neste artigo, procuramos adotar modelos de análise mais complexos para a abordagem da questão da identidade judaica na Ásia Menor do século I, e posteriormente da identidade cristã nesta mesma região em fins do século I e ao longo do século II. A partir da utilização do conceito de etnicidade proposto por Siân Jones, observamos que a identidade judaica no quadro da Ásia Menor se traduziu por um apego ao particularismo propriamente judaico em razão de processos sociais e culturais muito precisos: a constante hostilidade da população grega contra a comunidade judaica. Em outros locais onde as relações sociais entre judeus e a população circundante fossem cordiais, talvez tais judeus não tivessem se fechado no interior de sua comunidade e tivessem buscado uma integração maior com o mundo à volta deles. Mas este não foi o caso.

Somam-se ao cenário hostil em questão as relações próximas entre judeus e autoridades romanas, que Ihes garantiam privilégios, isenções especiais e, sobretudo, proteção contra as agressões sofridas. Por esses motivos, a resposta de tais judeus à pregação cristã do apóstolo Paulo nas sinagogas da Ásia Menor foi de repúdio violento à mensagem da chegada de um Messias crucificado que iria instaurar uma nova era, o Reino de Deus (em contraposição ao reino mundano de Roma).

A composição étnica das comunidades cristãs fundadas na Ásia Menor - de maioria absoluta de cristãos de origem não judaica e cultura grega - está diretamente relacionada ao contexto acima apresentado de repúdio judaico à pregação paulina. Se ao longo do século I d.C. indícios apontam para uma prática da judaização em comunidades cristãs paulinas ocorrida em razão de motivos variados, no século II d.C. nos parece muito provável que a motivação primeira para a construção

\footnotetext{
${ }^{14}$ Não queremos aqui reduzir o espectro de motivações para a prática da judaização pelos cristãos gentílicos da Ásia Menor a um único fator. Apenas enfatizamos que a questão de ordem político-social das perseguições romanas é muito forte e, por isso, não pode ser negligenciada no quadro de possíveis razões para a adoção de rituais judaicos por parte dos cristãos de origem gentílica.
} 
de uma identidade cristã 'judaizada' pelos cristãos de origem não judaica da Ásia Menor tenha sido a tentativa de fuga das perseguições do poder romano incitadas pela população gentílica daquela região.

Como pudemos perceber, o quadro de transformações históricas do judaísmo e do cristianismo na Ásia Menor dos séculos I e II d.C. deve ser visto como um cenário complexo no qual uma série de fatores se aliam de forma a dar movimento a história de ambas as vertentes religiosas.

\section{Agradecimentos}

Agradeço aos pareceristas que avaliaram o presente artigo pelos comentários de ordem formal e, em especial, pelas sugestões de atualização da historiografia discutida ao longo do texto, auxiliando-me a aprimorá-lo. A responsabilidade pelas ideias aqui apresentadas e por quaisquer faltas que, porventura, ocorram recai, no entanto, apenas sobre a minha pessoa.

\section{Referências}

ANDO, Clifford. Imperial Identitites. In: WHITMARSH, T. (Ed.). Local Knowledge and Microidentities in the Imperial Greek World. Cambridge: Cambridge University Press, 2010. p. 17-45.

BARCLAY, John M. G. Jews in the Mediterranean Diaspora. From Alexander to Trajan (323 BCE-117 CE). Edinburgh: T\&T Clark, 1996.

BÍBLIA. Português. Bíblia de Jerusalém. Novo Testamento. São Paulo: Paulus, 1994.

BOUSSET, Wilhelm. Kyrios Christos. Geschichte des Christusglaubens von den Anfängen des Christentums bis Irenaeus (FRLANT, nf 4). Göttingen: Vandenhoeck \& Ruprecht, 1913.

BROWN, Raymond E. An Introduction to the New Testament. New York: Doubleday, 1997.

COLLINS, John J. A Symbol of Otherness: Circumcision and Salvation in the First Century. In: . Seers, Sibyls and Sages in Hellenistic-Roman Judaism. Leiden, New York: Brill, 1997, p. 211-35. 
ERICKSON, Kyle. How to remember one's father: paternal images in the Seleucid Court. The School of Historical Studies Postgraduate Forum e-journal. Edition 7, 2010. Disponível em:<www.societies.ncl.ac.uk/shspgf/Ed_7/Erickson.pdf>. Acesso em: 9 ago. 2011.

FRANKFURTER, David. Jews or not? Reconstructing the "Other" in Rev. 2:9 and 3:9. The Harvard Theological Review, v. 94, n. 4, p. 403-425, Oct., 2001.

FREDRIKSEN, Paula. Judaism, the Circumcision of the Gentiles, and Apocalyptic Hope: Another Look at Galatians 1 and 2. Journal of Theological Studies, v. 42, n. 2, p. 532-64, 1991.

GOODMAN, M. A classe dirigente da Judeia. As origens da revolta judaica contra Roma (66-70 d.C.). Rio de Janeiro: Imago, 1994.

HENGEL, Martin. The Pre-Christian Paul. London: SCM Press, 1991.

HORSLEY, R. Paulo e o Império. Religião e poder na sociedade imperial romana. São Paulo: Paulus, 2004.

HURTADO, Larry W. One God, One Lord. Early Christian Devotion and Ancient Jewish Monotheism. London, New York: T\&T Clark, 1998.

JAEGER, Werner. Cristianismo Primitivo e Paidéia Grega. Lisboa: Edições 70, 1991.

JONES, Siân. The Archaeology of Ethnicity: constructing identities in the past and present. London, New York: Routledge, 1997.

JUSTINO de Roma. I e II Apologias. Diálogo com Trifão. Padres Apostólicos, São Paulo, v. 3, p. 13106, 1997.

KERESZTES, Paul. The Emperor Hadrian's Rescript to Minucius Fundanus. Phoenix, v. 21, n. 2, p. 120-129, Summer, 1967.

MURPHY-O'CONNOR, Jerome. Paulo. Biografia Crítica. São Paulo: Loyola, 2000.

MURRAY, Michele D. Playing a Jewish Game. Gentile Christian Judaizing in the First and Second Centuries CE. 2000. Tese (Doutorado em Filosofia) - Centro para Estudos de Religião. Toronto, University of Toronto, 2000.

MURRAY, Michele D. Playing a Jewish Game. Gentile Christian Judaizing in the First and Second Centuries CE. (Studies in Christianity and Judaism/Études sur le christianisme et le judaïsme 13). Waterloo, Ontario: Wilfrid Laurier University Press, 2004.

NESTLE-ALAND. Novum Testamentum Graece. Stuttgart: Deutsche Bibelgesellschaft, 1993. 
PLíNIO, o jovem. Cartas 10,96. In: FUNARI, P. P. A. Antiguidade Clássica: a história e a cultura a partir dos documentos. Campinas: Ed. Unicamp, 2002. p. 91-92.

PRICE, Simon R. F. Rituals and Power. The Roman imperial cult in Asia Minor. Cambridge: Cambridge University Press, 1984.

PUCCI BEN ZEEV, Miriam. Jewish Rights in the Roman World. The Greek and Roman Documents Quoted by Josephus. Tübingen: Mohr-Siebeck, 1998.

SANDERS, E. P. Paul, the Law, and the Jewish People. Minneapolis: Fortress Press, 1983.

SELVATICI, M. A Ásia Selêucida e os reinos asiáticos. In: MARQUES, J.B.; SELVATICI, M. O mundo helenístico. Rio de Janeiro: CECIERJ, 2012.

SELVATICI, Monica. Tradição Judaica, Cultura Helênica e Dinâmica Histórica: o Cristianismo de Paulo de Tarso em perspectiva. 2002. Dissertação (Mestrado em História Social) - UFRJ, Rio de Janeiro, 2002.

. Construção de fronteiras entre o judaísmo e o cristianismo no Império Romano: os judaizantes e a retórica antijudaica no movimento cristão dos séculos I e II d. C. Romanitas Revista de Estudos Grecolatinos, v. 1, p. 23-37. 2013.

Ethnicity and Ancient Judaism: Jewish Identities in 1st Century Alexandria and Antioch. In: FUNARI, Pedro Paulo; GARRAFFONI, Renata S.; LETALIEN, Bethany. (Org.). New Pespectives on the Ancient World: Modern Perceptions, Ancient Representations. Oxford: Archaeopress, 2008. p. 213-220.

Os Judeus Helenistas e a Primeira Expansão Cristã: questões de narrativa, visibilidade histórica e etnicidade no livro dos Atos dos Apóstolos. 2006. Tese (Doutorado em História) Campinas, Unicamp.

SENA PERA, Juan Pablo. O anti-judaísmo de Justino o Mártir no Diálogo com Trifão. 2009. Dissertação (Mestrado em História) - Universidade Federal do Espírito Santo, Vitória.

SMALLWOOD, E. Mary. The Diaspora in the Roman Period before CE 70. In: HORBURY, W.; DAVIES, W. D.; STURDY, J. The Cambridge History of Judaism, 3: The Early Roman Period. Cambridge: Cambridge UP, 1999. p. 168-191.

STRABO. Geography of Strabo. Translated with notes by H. C. Hamilton and W. Falconer. 2014. v. 3. Project Gutemberg. Disponível em:<www.gutenberg.org/files/ 44886/44886-h/44886-h.htm>. Acesso em: 20 maio 2015.

TRAJANO. Cartas 10,97. In: FUNARI, P. P. A. Antiguidade Clássica: a história e a cultura a partir dos documentos. Campinas: Ed. Unicamp, 2002. p. 92. 


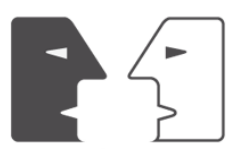

ANTÍTESES

TREBILCO, Paul. Jewish Communities in Asia Minor. Cambridge: Cambridge University Press, 1991. (Society for New Testament Studies / Monograph Series 69).

VAN HENTEN, J. W.; VAN DER HORST, P. W. Jewish Tomb Inscriptions in Verse, In: VAN DER HORST, P. W. Hellenism - Judaism - Christianity. Essays on their interaction. Kampen: Kok Pharos, 1994.

YARBRO COLLINS, A. Crisis and Catharsis. The Power of the Apocalypse Philadelphia: Westminster Press, 1984.

Recebido em 03.08.2015 - aprovado em 25.09.2015 